\title{
食品中の無機スズおよび有機スズ化合物の 薄層クロマトグラフィー
}

(昭和 46 年 10 月 12 日受理)

\author{
赤木洋勝* 藤田昌彦* 坂上米次*
}

\begin{abstract}
Thin Layer Chromatography of Inorganotin and Organotin Compounds in Foods
\end{abstract}

\author{
Hirokatsu AKAGI, Masahiko FUJITA, Yoneji SAKAGAMI
}

(Institute of Public Health: 4-6-1, Shirokanedai, Minato-ku, Tokyo)

In the previous paper, the authors reported on the thin layer chromatographic technique for the separation of inorganotin and organotin compounds.

In the present paper, a rapid and simple procedure was contrived for the identification of the tin compounds in foods by the thin layer chromatography.

The tin compounds added to foods were easily extracted with diethyl ether from the samples acidified with hydrochloric acid as they were or as their thiocyanates.

In the extraction procedure, the ether containd in the mixture of emulsion and suspension, which had been formed through vigorous shaking with each sample, was successfully separated by centrifugation using filter paper and the perforated disc made of "teflon".

After the extracts were evaporated to dryness, inorganotin and organotin compounds in the residues were identified on thin layer chromatography.

(Received_October 12, 1971)

\section{はしがき}

われわれは，前報1)において農薬ならびに塩化ビニル 樹脂の安定剤として使用される代表的な有機スズ化合物 の紫外線による分解について検討し, 各有機スズ化合物 が短時間の紫外線照射により, その一部が分解され, 種 々の有機スズ化合物と無機スズ化合物との混合物を生ず ることを認めた。したがって，農作物に付着した有機ス ズ化合物やポリ塩化ビニル中の有機スズ化合物なども長 期にわたる日光照射によって同様に分解を受け，種々の 形態で食品中に含まれるよらになると推定した。

従来, 食品污染にかかわる有機スズ化合物の分析に関 しては, ジアルキルスズのみが対象とされ，カテュール バイオレットのエタノール溶液 (油の場合) $)^{2)}$, ジチ・゙ン の 1，2-ジクロルエタン3またはへキサン溶液4など主 として溶媒抽出法によって食品からのクリーンアップが 行なわれている. しかしながら,これらの手法を適用で きる食品は限られ, 抽出に際して堅固なエマルジョンを 形成する食品では，抽出液を分離しがたいため，灰化後 無機スズの形で単離しなければならず, その化学形態に * 国立公衆衛生院：東京都港区白金台 4-6-1
ついて不明なことが多(4) 7).
そこで，われわれは食品中の種々のスズ化合物を薄層
クロマトグラフィー（以下 TLC と略す）によって分 析するための前処理法について検討した。すなわち, $\mathrm{Bock}^{8)}$ は多くの金属のチオシアン酸錯塩の水層からエ チルエーテルヘの移行性についての研究に氺いて, 無機 スズ（IV）が極めて有効に抽出されることを見出してい るので，本抽出法の有機スズおよび無機スズ化合物の同 時抽出性について検討すると共に, 食品からの抽出操作 の過程でェマルジョンが生じた場合の処理法についても 検討を行ない，極めて良好な結果を得たので報告する.

実験方法

1. 試料

(1) スズ化合物標準品：標準品として用いたスズ化合 物は Table 1 に示す10種で，いずれも TLC 上で他の スポットを認めなかった。添加実験用溶液および TLC 用標準溶液としては, 各々 $100 \mathrm{mg}$ をメタノール $100 \mathrm{ml}$ に溶解したものを使用した。

(2) 農作物および調味食品：農作物としてトマトを, 調味食品として醸造酢，䤑造しょう油およびンースを選 
Table 1. Chemical Formulas and their Abbreviations of Inorganotin and Organotin Compounds

\begin{tabular}{l|l|c}
\multicolumn{1}{c|}{ Compound } & Chemical formula & Abbreviation \\
\hline Tin tetrachloride & $\mathrm{SnCl}_{4}$ & TC \\
Mono- $n$-butyltin trichloride & $n-\mathrm{C}_{4} \mathrm{H}_{8} \mathrm{SnCl}_{8}$ & MBC \\
Di- $n$-butyltin dichloride & $\left(n-\mathrm{C}_{4} \mathrm{H}_{9}\right)_{2} \mathrm{SnCl}_{2}$ & DBC \\
Tri- $n$-butyltin chloride & $\left(n-\mathrm{C}_{4} \mathrm{H}_{9}\right)_{3} \mathrm{SnCl}$ & TBC \\
Mono-n-octyltin trichloride & $n-\mathrm{C}_{8} \mathrm{H}_{17} \mathrm{SnCl}_{3}$ & MOC \\
Di- $n$-octyltin dichloride & $\left(n-\mathrm{C}_{8} \mathrm{H}_{17}\right)_{2} \mathrm{SnCl}_{2}$ & DOC \\
Tri- $n$-octyltin chloride & $\left(n-\mathrm{C}_{8} \mathrm{H}_{17}\right)_{3} \mathrm{SnCl}$ & TOC \\
Mono-phenyltin trichloride & $\mathrm{C}_{6} \mathrm{H}_{5} \mathrm{SnCl}_{3}$ & MPC \\
Di-phenyltin dichloride & $\left(\mathrm{C}_{6} \mathrm{H}_{5}\right)_{2} \mathrm{SnCl}_{2}$ & DPC \\
Tri-phenyltin chloride & $\left(\mathrm{C}_{6} \mathrm{H}_{5}\right)_{3} \mathrm{SnCl}$ & TPC
\end{tabular}

び，いずれも市販品を使用した。

\section{2. 試莱およひ器具}

(1) チオシアン酸アンモニウム：精製メタノールで2 回再結晶したもの.

(2) エチルエーテル: 水酸化ナトリウム溶液と振り混 ぜ, 水洗後蒸留したもの。

(3) 円形口紙: 東洋濾紙 No.1を $50 \mathrm{ml}$ 用遠心分離 管の内径よりやや小さめに切取ったもの.

(4) テフロン製円形目皿板：円形ロ紙と同等の径を有 し, 厚さ $0.25 \mathrm{~mm}$ の目血板.

(5) 薄層: 薄層クロマトグラフィー用キーゼルゲル $\mathrm{H} 18 \mathrm{~g}$, 硫酸アンモニウム $2 \mathrm{~g}$ および水 $40 \mathrm{ml}$ を十分 混和し，これを用いて厚さ $0.3 \mathrm{~mm}$ の薄層を調製した のち, $110^{\circ} て ゙ 1$ 時間活性化したもの。

(6) 展開溶媒 (A) 四塩化炭素一头酢酸 $(14+6)$. (B) インオクタンーアセトンー皮酢酸 $(16+3.5+0.5)$. (C) イソオクタンーアセトン $(17+3)$.

(7) 発色試液: (i) $0.1 \%$ ジチゾンーアセトン溶液 (ii) $0.1 \%$ ピロカテコールハイイオレットーエタノール溶液.

その他の試薬および溶媒はいずれも試薬特級品をその まま用いたまた，TLCについては前報1によった。

\section{3. 水溶液からのスズ化合物の分離}

各分液ロートに水 $30 \mathrm{ml}$ をとり, 各スズ化合物のメタ

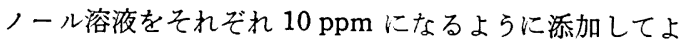
く振り混ぜ，これにチオシアン酸フンモニウム $3 \mathrm{~g}$ を加 えて溶かし， $2 \mathrm{~N}$-塩酸 $10 \mathrm{ml}$ を加えたのち，エチルェ ーテル $20 \mathrm{ml}$ で約 2 分間抽出した.

エーテル層を水 $10 \mathrm{ml}$ で 2 回洗い, 洗液は水層に合し た. また水層をエーテル $5 \mathrm{ml}$ で 2 回洗浄し, 洗液はェ ーテル㳟に合した。エーテル層はそのまま減圧下に蒸発 乾固したのち，少量のエタノールを加えて同様に蒸発乾 固し, 水層は $10 \%$ 水酸化ナトリウム溶液で中和後, これ を減圧下に蒸発乾固し，おのおのの残留物をメタノール 約 $0.5 \mathrm{ml}$ に溶かして TLC 用試料溶液とした.

\section{4. 食品中からのスス化合物の分離}

一定量のトマトを乳バチ中ですりつぶし，これに TPC，DPC，MPC および TCをそれぞれ 10 ppm にな るように添加し，その他の調味食品には，DOC，MOC および TC を同様に添加し，それぞれ一夜放置したも のについて，水溶液の場合と同様に操作して TLC 用試 料溶液を調製した。ただし，抽出操作において，エマル ジョンを生ずるものについては，これを遠心分離管にう つし， $3000 \mathrm{rpm}$ で10分間遠心分離したのち，分液を行 なった。

遠心分離によってもなおェマルジョン層がェーテル層 と水層との間に留まっているときは, そのエマルジョン 層上に円形ロ紙およびテフロン製円形目血板を順次の せ, 再び $3000 \mathrm{rpm}$ で10分間遠心分離を行ない, エーテ 儿層を分離した。

また，別にスズ化合物無添加の各食品について同様に 操作し, 比較用試料溶液とした。

\section{実験結果および考察}

\section{1. 水溶液からのスス化合物の分離}

試料中のスズ化合物の化学形態を TLCによって同定 するための試料溶液調製法としては, 試料中のすべての スズ化合物を同時にかつ効率よく抽出する必要がある.

Bock の方法汭は無機スズ (IV) をチオシアン酸錯塩と してェチルェーテルに移行させるものであるが，エチル エーテルによって, ジアルキルスズ化合物が効率よく抽 出されることから, 本抽出法の食品污染にかかわる無機 および有機スズ化合物の同時抽出性について，検討を行 なった。

本法におけるチオシアン酸アンモニウムの効果を知る ために, 各スズ化合物の水溶液にチオシアン酸アンモ二 ウムを添加したものと無添加のものについて，それぞ れエーテル抽出を行ない, 各水層およびェーテル層中の スズ化合物の有無を TLCによって確認した。 その結果 を Table 2 に示す. チオシアン酸アンモニウム無添加 
Table 2. Effect of Ammonium Thiocyanate in the Proposed Extraction Procedure for the Detection of Inorganotin and Organotin Compounds on the Thin Layer Chromatogram

Ammonium thiocyanate

\begin{tabular}{|c|c|c|c|c|}
\hline \multirow[t]{2}{*}{ Compound } & \multicolumn{2}{|c|}{ None } & \multicolumn{2}{|c|}{ Added } \\
\hline & Ether layer & Aqueous layer & Ether layer & Aqueous layer \\
\hline $\mathrm{TC}$ & \pm & $H$ & $H$ & - \\
\hline $\mathrm{MBC}$ & $H$ & \pm & $H$ & - \\
\hline MOC & $H$ & - & $H$ & - \\
\hline MPC & $H$ & \pm & H & - \\
\hline $\mathrm{DBC}$ & $H$ & - & H & - \\
\hline $\mathrm{DOC}$ & $H$ & - & $H$ & - \\
\hline DPC & H & - & H & - \\
\hline $\mathrm{TBC}$ & + & - & + & - \\
\hline TOC & + & - & + & - \\
\hline TPC & + & - & + & - \\
\hline
\end{tabular}

H: very clear, + : clear, \pm : slightly detectable, - : non-detectable

のものでは, エーテル層中にほとんどすべての有機スズ 化合物が検出され，水層には極微量の MBC, MPC お よび多量の TC の残存が認められた。一方, チオシアン 酸アンモニウム添加の抽出条件においては, エーテル層 中にすべてのスズ化合物が多量検出され，水層にはまっ たくスズ化合物の残存は認められなかった。 また，この 抽出条件で, $\mathrm{Sn}^{2+}$ も $\mathrm{Sn}^{4+}$ と同様ほぼ完全に抽出さ れ，本法は TLC のためのスズ化合物のクリーンフップ として極めて有効であることを認めた。

なお，本法において，チオシアン酸アンモニウムを塩 酸々性溶液中に溶かすとき，ただちに赤色を帯び，この 着色物質はェーテル抽出により, エーテル層に移行した が，エーテルを減王下に蒸発乾固後, 少量のエタノール を加えて再び乾固するとき，それをほぼ完全に除去する ことができた。

\section{2. 食品中のスス化合物の分離検定について}

(1) チオシアン酸アンモニウムーエチルエーテルによ る抽出

水溶液からのスズ化合物の分離法として好結果をえた チオシアン酸アンモニウムーエチルエーテルによる抽出 法を，無機スズおよび有機スズ化合物を添加した食品に 応用した。

醉造酢からの抽出においては, 水溶液の場合と同様に 分液ロートにより，容易にエーテル層を分離することが できた。しかしながら、ソース，しょら油およびトマト では, エチルエーテルと振とうするとき，エマルジョン が生じ, 分液口ートでの分液は不可能であったため, そ れらをそれぞれ遠心分離管にうつし，3000 rpm で10分 間遠心分離を行なった。 その結果, ソースおよびしょう油では, 大半のエーテ
ル層をとり出し得たが，トマトについては，エマルジョ ン層がェーテル層と水層および固形分との間にかなりの 厚さをもって存在し，わずかのエーテル層を分離したに とどまった。ささらに，遠心分離操作を $4000 \mathrm{rpm}$ で10分 間行なってもほぼ同様な結果に終った。

(2) エマルジョン層中のエチルェーテルの分離につ いて

エマルジョンの形成は，溶媒抽出法においてしばしば おこる現象であるが，これを簡便に破壊する方法はほと んど見当らない.

われわれは，エマルジョンを破壊するために，遠心分 離操作に改良を加えた。すなわち, 食品とェチルエーテ ルとの混合物を予め $3000 \mathrm{rpm}$ で10分間遠心分離したの ち,エマルジョン層上に円形ロ紙およびテフロン製円形 目血板を順次のせ，再び $3000 \mathrm{rpm} て ゙ 10$ 分間遠心分離を 行なった。

その結果，テフロン製円形目皿板および円形ロ紙がェ マルジョン層と共に遠心分離管の底部まで沈降し，エー テル層をほぼ完全に分離することができた。

この原因は，遠心分離によって，比重 2.2 を有するテ フロン製円形目皿板が円形ロ紙と共にエマルジョン層を 圧して沈降し,さらにェマルジョン層が遠心分離管の底 部で圧縮され，この間にェマルジョン層中の液相が強制 口過されたものと考えられる。

この方法において，テフロン製円形目皿板が厚すぎる と, その重量のために, それのみが急速に沈降し，エマ ルジョン層を全体的に圧することができないばかりでな く, 底部での圧縮の際，底面に沿って湾曲しえない。本 法では厚さ $0.25 \mathrm{~mm}$ のものを使用し, その目的を十分 達することができた。 
（3）スズ化合物の TLCによる検出

以上の操作によって得られたエーテル層を水洗し，エ チルェーテルを減圧下に留去したのち, 少量のエタノー ルを加えて再び蒸発乾固し，そのメタノール溶液につい て，前報1ににしたがってそれぞれ TLCを行なった。

その結果，いずれの試料についても，有機スズ化合物 の検出に妨害となる物質は認められなかったが，原点付 近に, TC 以外の金属イオンと思われるジチン゙ンによっ て呈色するものの存在を認めた。この物質は, 各比較用 試料溶液の分析の結果, ジチゾンにより桃赤色を呈し, ピロカテコールバイオレットにより何ら呈色を与えない ことから，Znイオンと思われた。

\section{3. その他の金属イオンの影響について}

チオシアン酸 アンモニウムーエチルエーテルによるス ズ化合物の抽出およびその TLCにおける各金属イオン の影響について検討した。

金属化合物として, $\mathrm{HgCl}_{2}, \mathrm{AgNO}_{3}, \mathrm{SnCl}_{2} \cdot 2 \mathrm{H}_{2} \mathrm{O}$, $\mathrm{ZnSO}_{4} \cdot 7 \mathrm{H}_{2} \mathrm{O}, \mathrm{CuSO}_{4} \cdot 5 \mathrm{H}_{2} \mathrm{O}, \mathrm{FeCl}_{3} \cdot 6 \mathrm{H}_{2} \mathrm{O}, \mathrm{Pb}\left(\mathrm{NO}_{3}\right)_{2}$ および $\mathrm{Cd}\left(\mathrm{NO}_{3}\right)_{2} ・ 4 \mathrm{H}_{2} \mathrm{O}$ の 8 種をえらび，各 $100 \mathrm{mg}$ おのおの水 $30 \mathrm{ml}$ に溶かしたものについて, 実験方法 3 にしたがって試料溶液を調製し，四塩化炭素一氷酢酸 $(14+6)$ を展開溶媒として TLC を行ない，0.1\% ジチ ゾン溶液または $0.1 \%$ ピロカテコールバイオレット溶液 を用いて発色を行なった， その結果を Table 3 に示す.

展開は TC, MPC, MBC および MOC 用の展開溶

Table 3. Thin Layer Chromatographic Detection of Ether Extract of Thiocyanates of the Metal

\begin{tabular}{c|l|l} 
Retal ion & \multicolumn{1}{|c|}{ Dithizone } & \multicolumn{1}{|c}{$\begin{array}{c}\text { Pyrocathecol } \\
\text { violet }\end{array}$} \\
\cline { 2 - 2 } $\mathrm{Sn}^{2+}$ & \#(Red purple) & H(Blue) \\
$\mathrm{Zn}^{2+}$ & H(Red pink) & \pm (Yellow orange) \\
$\mathrm{Fe}^{3+}$ & $+($ Yellow) & H(Purple) \\
$\mathrm{Ag}^{+}$ & +(Yellow orange) & - \\
$\mathrm{Pb}^{2+}$ & $\pm($ Yellow brown) & - \\
$\mathrm{Cu}^{2+}$ & - & - \\
$\mathrm{Cd}^{2+}$ & - & - \\
$\mathrm{Hg}^{2+}$ & - & -
\end{tabular}

H: very clear, + : clear,

\pm : slightly detectable, - : non-detectable

Adsorbent: $10 \%$ ammonium sulfate-containing Kieselgel $\mathrm{H}$

Solvent system: carbon tetrachloride-acetic acid $(14+6)$
液を用いて行なったが，呈色した各金属イオンのスポッ トはいずれも原点であった.

Table 3 に示すよらに，ジチ・゙ン溶液による発色にお

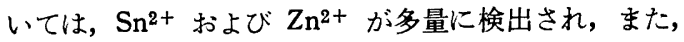
$\mathrm{Ag}^{+}$および $\mathrm{Fe}^{8+}$ も検出された.

一方, ピロカテュールバイオレット溶液による発色で は, $\mathrm{Sn}^{2+}$ および $\mathrm{Fe}^{8+}$ の呈色が強く現われ, $\mathrm{Zn}^{2+}$ も わずかに検出された。

これらの金属イオンは前述のように，原点に留まり， $\mathrm{Sn}$ イオンのスポットと分離しえなかったが， $\mathrm{Sn}^{2+}$ およ び $\mathrm{Sn}^{4+}$ は共に，いずれの発色試薬とも極めて鋭敏に反 応するため, それら 2 種の発色試薬を用いれば, それら の呈色の特異性により，スズイオンの存在を容易に知る ことができると考えられる。

結語

食品中に混在する可能性のある一連の無機スズおよび 有機スズ化合物をTLCによって検出するための食品中 からのクリーンフップ法について検討した.

その結果, 各スズ化合物は塩酸々性溶液から,塩化物ま たはチオシアン酸塩としてェチルェーテルにほぼ定量的 に抽出され, 無機スズおよび有機スズ化合物の同時抽出 法として極めて有効であることを認めた。 また，これら の食品からの抽出操作において, しばしば形成されるエ マルジョンは, 円形ロ紙およびテフロン製円形目皿板を 用いて遠心分離するとき，容易に破壊され，エマルジョ ン中のエーテル分をほぼ完全に分離することができた。

文献

1）赤木洋勝, 坂上米次: 公衆衛生院研究報告 20 (1), 1 (1972).

2) Adamson, J.H.: Analyst 87, 597 (1962).

3) 小松美博, 並木恒久, 森 文雄: 食衛誌。11, 17 (1970).

4) Larkin, W.A., Sheldon, A. W., Simmons, I. L.: 26 th Annual Technical Conference of the Society of Plastic Engineers. New York, May, 1968; 塩ビ食品衛生協議会：技術参考資料 22 号, 10 (1969).

5）塩ビ食品衛生協議会：塩ビ食品衛生協議会 報 No. 4, 48 (1968).

6) Corbin, H. B.: J. Assoc. Offic. Anal. Chemists 53, 140 (1970).

7) 山畑慧位子, 楠山 尚, 小西一生: 分析化学 20, 223 (1971).

8) Bock, R.: Z. Anal. Chem. 133, 110 (1951). 